\title{
Noa \& Max. Atrapats a Electrònia: la primera sèrie d’animació per a generar interès per la ciència i la tecnologia entre els joves
}

\author{
Sergio Marco del Fresno (Sergio.marco.del.fresno@everis.com) \\ Director del programa Everis STEM Education
}

"Noa \& Max. Atrapats a Electrònia" és la primera sèrie d'animació online creada per la consultora multinacional Everis i la Universitat Pompeu Fabra (UPF), i que ha estat inclosa en el programa de cultura científica i de la innovació 2012 de la Fundació Espanyola per a la Ciència i la Tecnologia (FECYT). Compta amb el suport d'organitzacions i entitats tant de l'àmbit públic com privat, entre les que es troba el CRECIM de la UAB.

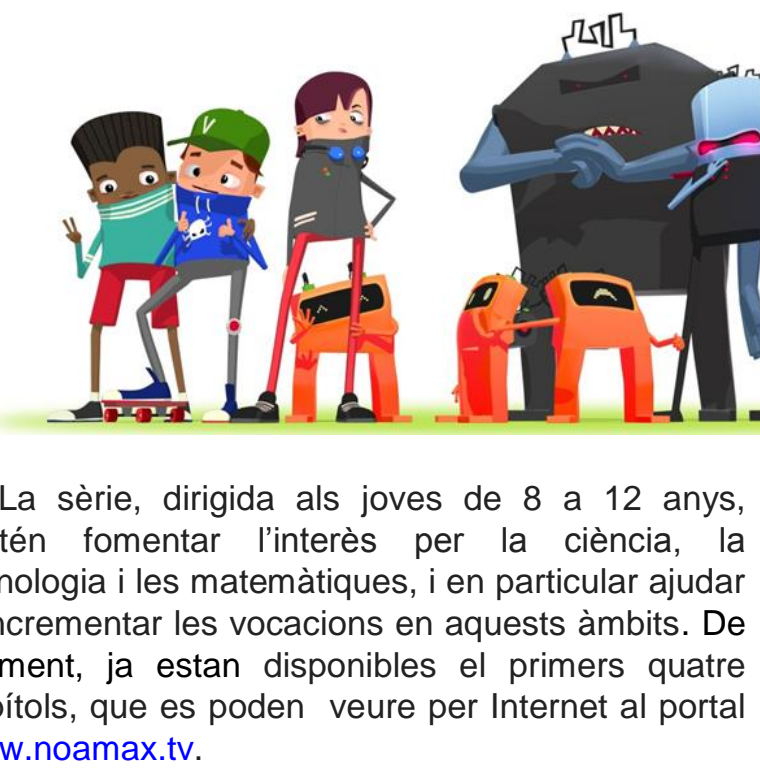

La Noa (14 anys) i el Max (12 anys), els dos germans protagonistes, no són estudiants destacats $\mathrm{i}$ els seus interessos, com en la majoria de nens de la seva edat, es troben més en la música o l'skate que no pas en la ciència o els estudis, (els quals sovint no els veuen connectats amb la seva realitat). En la sèrie, la Noa i el Max han quedat atrapats a Electrònia, el videojoc més famós de tots els temps. Per sortir, hauran d'emprar els seus coneixements sobre ciència $i$ tecnologia així com descobrir solucions a través de l'experimentació empírica i l'observació dels fenòmens que els envolten, per poder tornar a casa seva i evitar que en Lord Tek, el malvat dictador d'Electrònia, els atrapi.

En les trames de ficció, on s'hi plantegen petits reptes científics i tecnològics, es pretén millorar la percepció dels joves de la seva pròpia capacitat per entendre i poder estudiar fenòmens científics i tecnològics, així com potenciar la seva creativitat i talent innovador. No es tracta, tanmateix, d'un material educatiu curricular, on s'explica detalladament el fonament científic d'un determinat fenomen. Els continguts de ciència i tecnologia hi apareixen de manera clara i central, però perfectament integrats en la trama i de manera espontània, sense forçar la seva presentació ni agafant massa protagonisme.

\section{LA MOTIVACIÓ}

La sèrie sorgeix de la preocupació per la manca de professionals científics i tecnològics, juntament amb la creixent caiguda de les vocacions en aquest àmbit entre els joves.

En l'estudi sobre la manca d'enginyers TIC (everis 2012), es posa de manifest la magnitud del problema: disminució del $6 \%$ en el nombre d'alumnes en batxillerats científics i tecnològics (exclou ciències de la salut) en el període 20012010 , amb una presència de només un $4 \%$ de noies a les branques tecnològiques, i que s'acaba 
traduint en una caiguda del $46 \%$ en les matriculacions a les enginyeries TIC.

Per contra, els professionals TIC són dels més demandats en el mercat laboral, fins al punt que la Comissió Europea ha publicat recentment que, segons les seves previsions, el nombre de llocs de treball que quedaran vacants a Europa en aquest sector al 2015 superarà els 900.000 . I les nostres xifres d'atur juvenil segueixen per sobre del $50 \%$.

És necessari, doncs, entendre en profunditat les causes del problema per actuar amb eficàcia si volem revertir aquesta tendència.

\section{Una sèrie que neix per un estudi d'everis}

El disseny i creació de la sèrie vénen recolzats per les conclusions de l'estudi realitzat per everis sobre els factors d'influència en la decisió dels estudis a secundària, realitzat a gairebé 5.000 estudiants d'ESO i batxillerat. L'estudi, realitzat amb el suport tècnic de la consultora e-motiva i amb el del Departament d'Ensenyament, indaga en el procés de decisió dels estudis futurs dels alumnes des de les seves percepcions, i en particular en els factors diferencials que porten a escollir 0 descartar els estudis de ciència i tecnologia.

La investigació revela, com a principals conclusions, que:

- Els alumnes valoren molt positivament els estudis i professions de ciència i tecnologia: majoritàriament pensen que tenen prestigi i saben que representen bones sortides professionals.

- El factor més important per descartar l'opció de ciència i tecnologia com a via de futur es troba en la baixa percepció de capacitat per cursar aquestes matèries que els alumnes tenen de sí mateixos. Al voltant del $50 \%$ de l'alumnat no es veu capaç de cursar aquest tipus d'estudis, i veuen com a "massa difícil" tot allò que envolta la ciència i la tecnologia.

- El cas de les noies és especialment crític, molt especialment en relació a la tecnologia, i s'apunta a la manca de models de referència com un dels possibles factors que hi influeixen negativament.
- Internet i els programes de TV són la principal font de consulta per escollir estudis que els alumnes declaren, tan sols per darrera dels pares, per la qual cosa hem de tenir molt en consideració aquests canals de comunicació en l'orientació professional dels joves.

- La decisió es conforma a primària; a $3 r$ d'ESO la majoria dels alumnes ja té clar si anirà o no cap a un itinerari científico-tecnològic o no. Per canviar-ho, cal actuar abans, en alumnes que no han arribat a l'ESO o tot just comencen.

Per tant, és important impulsar iniciatives de millora de la motivació dels nens envers la ciència i la tecnologia, amb missatges d'apoderament que canviïn l'autopercepció negativa de les seves capacitats i el seu potencial i que els mostrin models de referència $a m b$ els que es puguin identificar i als que vulguin emular.

D'aquesta manera, neix la idea d'una "campanya" de promoció i conscienciació, que sent llançada a través d'internet i la TV i enfocada a nens per sota dels 12 anys, s'articula a través d'una sèrie d'animació: "Noa i Max. Atrapats a Electrònia".

\section{Més enllà de la sèrie}

La sèrie ha de permetre, addicionalment, despertar consciència sobre aquesta situació i les seves causes entre els pares, professors i centres escolars, com a principals agents en el procés educatiu, i també en l'administració pública i la indústria que, com demostren iniciatives com aquesta, es poden involucrar i participar activament en col-laboració amb la comunitat educativa.

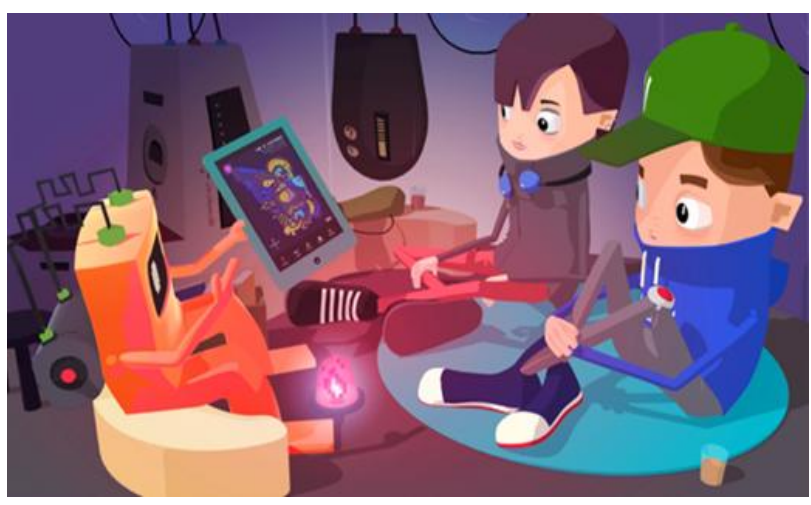

